\title{
Cross-shelf variation in carbon-to-chlorophyll $a$ ratios in the East China Sea, summer 1998
}

\author{
Jeng Chang ${ }^{\mathrm{a}, *}$, Fuh-Kwo Shiah ${ }^{\mathrm{b}}$, Gwo-Ching Gong ${ }^{\mathrm{c}}$, Kuo Ping Chiang ${ }^{\mathrm{d}}$ \\ ${ }^{a}$ Institute of Marine Biology, National Taiwan Ocean University, Keelung 202-24, Taiwan, ROC \\ ${ }^{\mathrm{b}}$ Institute of Oceanography, National Taiwan University, Taipei 106, Taiwan, ROC \\ ${ }^{\mathrm{c}}$ Department of Oceanography, National Taiwan Ocean University, Keelung 202-24, Taiwan, ROC \\ ${ }^{\mathrm{d}}$ Institute of Fishery Science, National Taiwan Ocean University, Keelung 202-24, Taiwan, ROC
}

Received 15 December 2002

\begin{abstract}
Spatial variations of the phytoplankton carbon-to-chlorophyll $a$ ratio $(\mathrm{C}: \mathrm{chl} a)$ in the East China Sea were investigated during a June 1998 cruise. Based on a regression analysis between particulate organic carbon and chlorophyll $a$ concentrations measured at 2-m depths, estimated values of C:chl $a$ were 13.0 and $92.8 \mathrm{~g} \mathrm{~g}^{-1}$ for coastal and offshore waters, respectively. In addition, water samples were collected from 5-m depths at three stations with different hydrographic characteristics, and phytoplankton carbon biomass was estimated from microscope-measured cell volumes. At the coastal zone station, chlorophyll $a$ concentration reached $7.9 \mathrm{mg} \mathrm{m}^{-3}$ with Skeletonema costatum as the dominant species. The total phytoplankton carbon was $142.8 \mathrm{mg} \mathrm{m}^{-3}$, and the estimated C:chl $a$ was $18.0 \mathrm{~g} \mathrm{~g}^{-1}$. At the midshelf station, Synechococcus spp. and Pseudosolenia calcar-avis were the major contributors to phytoplankton carbon. The chlorophyll $a$ concentration was $1.3 \mathrm{mg} \mathrm{m}^{-3}$, and C:chl $a$ was $67.4 \mathrm{gg}^{-1}$. In contrast, chlorophyll $a$ concentration decreased to $0.1 \mathrm{mg} \mathrm{m}^{-3}$ at the Kuroshio station, where the filamentous cyanobacteria Trichodesmium spp., contributed to most of the phytoplankton carbon, and C:chl $a$ was estimated to be $94.4 \mathrm{gg}^{-1}$. The C:chl $a$ ratios estimated by the two methods were in close agreement, and a linear relationship was established between the logarithm of chlorophyll $a$ concentration and phytoplankton carbon. The estimated carbon biomass was used to calculate intrinsic growth rates of phytoplankton in the East China Sea. The results indicate that phytoplankton grow actively in the coastal zone, with growth rates often higher than $1.4 \mathrm{day}^{-1}$, but much lower rates were observed near the margin of the continental shelf.
\end{abstract}

(C) 2003 Elsevier Science Ltd. All rights reserved.

\section{Introduction}

In the study of pelagic ecosystems, it is often desirable to express phytoplankton biomass as the

\footnotetext{
*Corresponding author. Tel.: +886-2-2462-2192/ext. 5308; fax: $+886-2-2463-3152$.

E-mail address: jengchang@mail.ntou.edu.tw (J. Chang).
}

amount of organic carbon. This practice provides a convenient way to compare the biomass of phytoplankton with that of other organisms such as bacteria (Buck et al., 1996). Carbon content is also the only way to represent phytoplankton biomass in a biogeochemical model that includes non-living carbon reservoirs. Another usage of phytoplankton carbon is to calculate the mean 
growth rate of an autotrophic community based on primary productivity measurements (Redalje and Laws, 1981).

However, phytoplankton carbon is difficult to measure in the ocean. Instead, chlorophyll $a$ concentration is routinely measured to represent phytoplankton biomass in practice. As a result, a carbon-to-chlorophyll $a$ ratio $(\mathrm{C}: \mathrm{chl} a)$ is commonly used to convert measured chlorophyll $a$ to phytoplankton carbon (e.g., Cho and Azam, 1990). The problem with using such a conversion factor is that the relationship between chlorophyll $a$ concentration and phytoplankton carbon is not constant. In pure cultures of phytoplankton, C:chl $a$ can vary between 10 and $100 \mathrm{~g} \mathrm{~g}^{-1}$ according to light levels, nutrient availability, and temperature (Cullen, 1982; Geider, 1993). In the open ocean, C:chl $a$ values much higher than 100 have been frequently reported in the surface zone (Buck et al., 1996). Using the relationship between phytoplankton production and environmental factors, Taylor et al. (1997) were able to simulate the seasonal, latitudinal, and vertical variations of $\mathrm{C}: \mathrm{chl} a$ with a mathematical model and then generated C:chl $a$ values comparable to those estimated experimentally in the open ocean.

In contrast, relatively little is known about the variability of C:chl $a$ in shelf seas and coastal waters. C:chl $a$ in San Francisco Bay has been shown to have a mean value of $51 \mathrm{~g} \mathrm{~g}^{-1}$ with only small variations between different regions of the bay (Wienke and Cloern, 1987). In a diatom bloom occurring along the coast of Washington State, USA, C:chl $a$ was estimated to be 20 to $30 \mathrm{~g} \mathrm{~g}^{-1}$ in winter and 50 to $75 \mathrm{~g} \mathrm{~g}^{-1}$ in summer (Schaefer and Lewin, 1984). However, these were all sporadic measurements done in very restricted regions, and are unsuitable for use as the representative $\mathrm{C}: \mathrm{chl} a$ of the entire shelf sea, which is characterized by steep hydrographic gradients.

The East China Sea occupies a major portion of the continental shelf in the western North Pacific. As a transition zone between the Asian continent and the open ocean, this shelf sea is a very active site of carbon cycling. A recent observation indicates that the East China Sea behaves as a $\mathrm{CO}_{2}$ sink by absorbing about $0.03 \mathrm{Gt}$ of atmospheric carbon per year (Peng et al., 1999). On the other hand, a conspicuous portion of its organic carbon is transported across the shelf break by currents and enters the deep ocean (Liu et al., 1995). Phytoplankton certainly plays important roles in these processes, and an understanding of the spatial variation of phytoplankton carbon in the East China Sea would be helpful in the construction of a carbon flow model.

For this report, we conducted a study to measure phytoplankton carbon biomass and C:chl $a$ in the East China Sea. Two independent techniques, one based on the regression between particulate organic carbon (POC) and chlorophyll $a$ concentrations and the other based on cell volume, were used to avoid biases inherently associated with each method (Mullin et al., 1966; Banse, 1977). According to the measured data, an empirical relationship between phytoplankton carbon and chlorophyll $a$ was established, and the spatial variation in the $\mathrm{C}: \mathrm{chl} a$ ratio was defined. Subsequently, as a first application of this relationship, the estimated phytoplankton carbon biomass was combined with ${ }^{14} \mathrm{C}$-measured primary productivity to calculate phytoplankton growth rates in the East China Sea.

\section{Materials and methods}

A cruise to the East China Sea was conducted on board the R/V Ocean Researcher I from June 28 to July 7, 1998. The cruise track covered seven cross-shelf transects, and in total 34 stations were visited (Fig. 1). A SeaBird CTD was used to gather temperature and salinity (Practical Salinity Scale) data while water samples for chlorophyll $a$, POC, and nutrient measurements were collected by 20-1 Go-Flo bottles at 2-m depths. Additional samples at greater depths also were collected at selected stations. The chlorophyll $a$ samples were prepared by filtering 0.6 to 2.21 of sea water through a GF/F filter, after which the filter was stored at $-20^{\circ} \mathrm{C}$ until analysis. The amount of chlorophyll $a$ on the filter paper was determined according to standard procedures using a Turner Designs 10-AU-005 fluorometer with the contribution of phaeopigments corrected for by acidification (Parsons et al., 1984; Gong et al., 1993). Samples for nutrient 


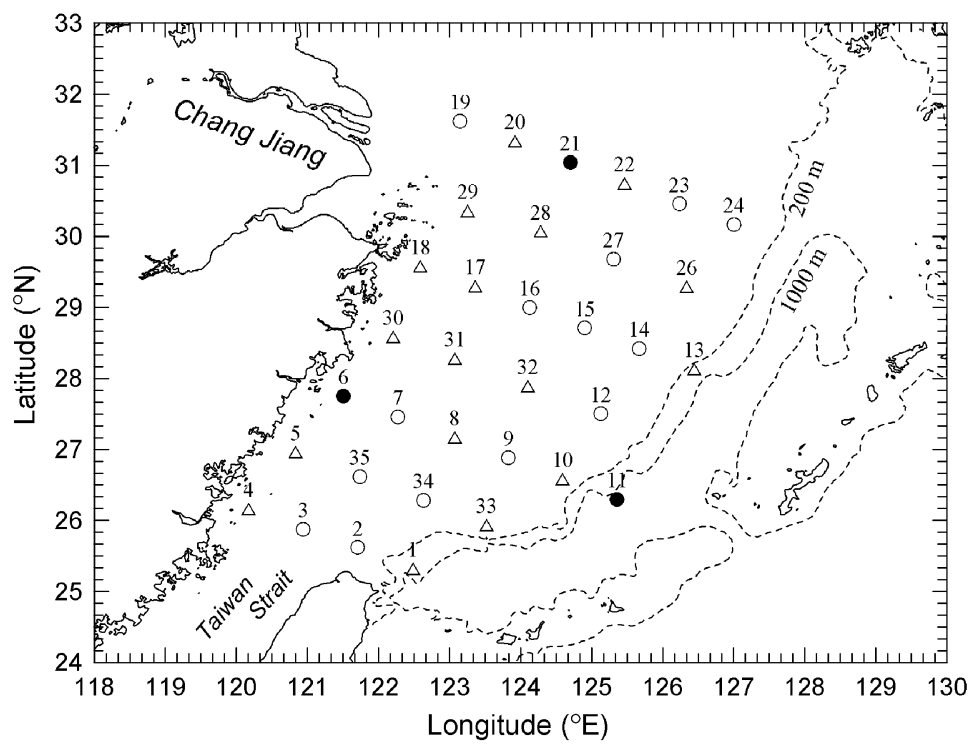

Fig. 1. Location of sampling stations in the East China Sea. $(\triangle)$ : Stations at which primary productivity was measured in addition to chlorophyll $a$ and POC; : stations at which samples were taken for the determination of cell volume.

analysis were quickly frozen in liquid nitrogen and stored at $-20^{\circ} \mathrm{C}$. The concentration of nitrate was determined by the pink azo dye method and the concentration of phosphate was determined by the molybdenum blue method using a self-designed flow injection system (Parsons et al., 1984; Gong, 1992). Samples for POC determination were prescreened with a $200-\mu \mathrm{m}$ mesh to remove zooplankton. Next, 0.5 to 11 of sea water was filtered through a precombusted $\left(550^{\circ} \mathrm{C}, 1 \mathrm{~h}\right) \mathrm{GF} / \mathrm{F}$ filter under low vacuum $(<100 \mathrm{mmHg})$. The $\mathrm{GF} / \mathrm{F}$ filter was then wrapped in an aluminum foil and stored at $-4^{\circ} \mathrm{C}$. Total organic carbon on each filters was determined on a CHN analyzer (Fisons NA1500) after the samples had been dried and acid-fumed (Liu et al., 1995). A linear regression was performed with POC and chlorophyll $a$ concentrations as the dependent and the independent variables, respectively, and the regression coefficient was used as an estimate of the C:chl $a$ ratio (Banse, 1977). Model I regression was applied to the data set because only results from Model I regression could be used for prediction purposes (Sokal and Rohlf, 1995).

Samples for cell volume and abundance measurements were collected from 5-m depths at three selected stations located in the coastal, the mid- shelf, and the Kuroshio regions, respectively (Fig. 1). The samples for examining cells greater than $5 \mu \mathrm{m}$ in size were prepared by placing 11 of sea water in a sample bottle with the addition of acidic Lugol's solution (Parsons et al., 1984). For the examination of ultraplankton cells $(<5 \mu \mathrm{m}$ in size), $5 \mathrm{ml}$ of sea water were filtered through a $0.2-$ $\mu \mathrm{m}$-pore Nuclepore filter. The filter was then mounted on a slide with a drop of immersion oil, and stored at $-20^{\circ} \mathrm{C}$ until microscopic examination.

Cells in the Lugol's preserved samples were concentrated twice by settling, through which the sample volume was reduced to $5 \mathrm{ml}$ (Sukhanova, 1978). The concentrated sample was mounted on a slide and examined using a Nikon Optiphot-2 microscope equipped with a SenTech STC-40 video camera and a Sony UP-860 video graphic printer. The image of phytoplankton cells was preserved on thermal paper and the dimensions of a cell were measured with the image of a stage micrometer taken at the same magnification. The thickness of a cell, however, was determined by focusing on the cell's upper and lower surfaces in turn, and the difference in the scales engraved on the fine-focus knob was used as the best estimate (Bradbury, 1991). The cell volume was computed 
from measured dimensions by assigning an appropriate geometrical shape to each species (Furuya and Nemoto, 1986; Hillebrand et al., 1999). Next, the volume of individual cells was converted to carbon content using the equations listed in Strathmann (1967). The carbon content of Trichodesmium trichomes was taken from Carpenter (1983). For numerically dominant species, more than 30 cells were measured to obtain a mean carbon content of those species. Fewer cells $(\sim 1-$ 14) were measured for less-dominant species. All cell volume measurements were completed within 4 months from the sampling date.

The natural abundance of each phytoplankton species was estimated by enumerating cells on a Sedgwick-Rafter counting slide (Guillard, 1978). Cells greater than $15 \mu \mathrm{m}$ in size were counted at 100X, while cells with a size between 5 and $15 \mu \mathrm{m}$ were counted at $400 \mathrm{X}$ using a long working distance objective. The cells of Skeletonema costatum were counted on a Palmer-Maloney slide due to its extremely high population density. The identification and scientific names assigned to each species were based on Tomas (1996). Ultraplankton cells collected on Nuclepore filters were measured and counted under a fluorescence microscope at $1000 \mathrm{X}$. About 40 cells were used for cell volume measurement, and cells in about 30 microscope fields $($ dia. $=153 \mu \mathrm{m})$ were enumerated for the estimation of natural abundance. Cell volumes were converted to carbon content using an equation established by Verity et al. (1992). The amount of organic carbon contributed by each phytoplankton group was the product of the mean cellular carbon content and the natural abundance. Total phytoplankton carbon was obtained by summing up the carbon biomass of all phytoplankton groups.

Primary productivity was measured at 18 selected stations by the ${ }^{14} \mathrm{C}$ assimilation method (Parsons et al., 1984) (Fig. 1). Water samples were taken at 2-m depths and were pre-filtered through a $200-\mu \mathrm{m}$ mesh. The filtered samples were then placed in $250-\mathrm{ml}$ incubation bottles, and $10 \mu \mathrm{Ci}$ $\mathrm{NaH}^{14} \mathrm{CO}_{3}$ was added to each bottle. After a 2-h incubation period at various levels of artificial irradiance, the samples were filtered onto $\mathrm{GF} / \mathrm{F}$ filters, and the radioactivity retained on the filters was measured on a Packard 2700TR scintillation counter. The resultant photosynthesis-irradiance relationship was then used to estimate the daily primary production at individual stations (Jassby and Platt, 1976). Phytoplankton growth rates $(\mu)$ in the East China Sea were estimated based on the following equation (Cloern et al., 1995):

$\mu=0.85 P^{\mathrm{B}}\left(\frac{[\mathrm{Chl} . \mathrm{a}]}{C_{\mathrm{P}}}\right)-0.015$,

where $P^{\mathrm{B}}$ is the chlorophyll specific primary productivity, and $C_{\mathrm{P}}$ is the phytoplankton carbon biomass. Constant terms in the equation are used to include the effect of respiration.

\section{Results}

\subsection{Hydrography}

During our survey, the hydrographical characteristics of the East China Sea showed a typical pattern with cold but nutrient-rich coastal water fringing the mainland coast and the warm, oligotrophic Kuroshio flowing along the shelf break (Figs. 1 and 2). In the midshelf region, the
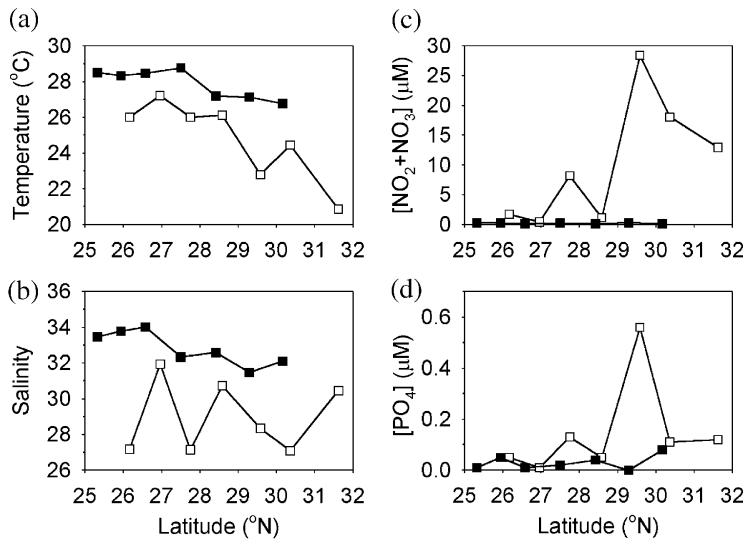

Fig. 2. Hydrographic characteristics in the coastal and the Kuroshio zones in the East China Sea: (a) water temperature, (b) salinity, (c) nitrate and nitrite concentration, and (d) phosphate concentration at $2-\mathrm{m}$ depths. The coastal zone stations ( $\square$ ) included Stas. 4, 5, 6, 30, 18, 29, and 19 (from south to north), and the Kuroshio zone ( $\boldsymbol{\square}$ ) was represented by Stas. 1, 33, 10, 12, 14, 26, and 24. 
mixing of these two vastly different water masses with the Taiwan warm current formed a wide mixing zone (for a review, see Wong et al., 2000). At a typical coastal station (Sta. 6), temperature and salinity profiles indicated a strong influence of fresh water near the surface, with salinity readings lower than 27.5 (Fig. $3 \mathrm{a}$ and b). The combined concentrations of nitrate and nitrite were high throughout the water column, and the chlorophyll $a$ concentration reached $7.9 \mathrm{mg} \mathrm{m}^{-3}$ at a $2-\mathrm{m}$ depth (Fig. 3c and d). Compared to other coastal stations, water temperature at Sta. 6 fitted well to a trend of decreasing temperature from south to north (Fig. 2a). In contrast, salinities in the coastal zone varied erratically between 27 and 32, apparently a result of local fresh water discharge
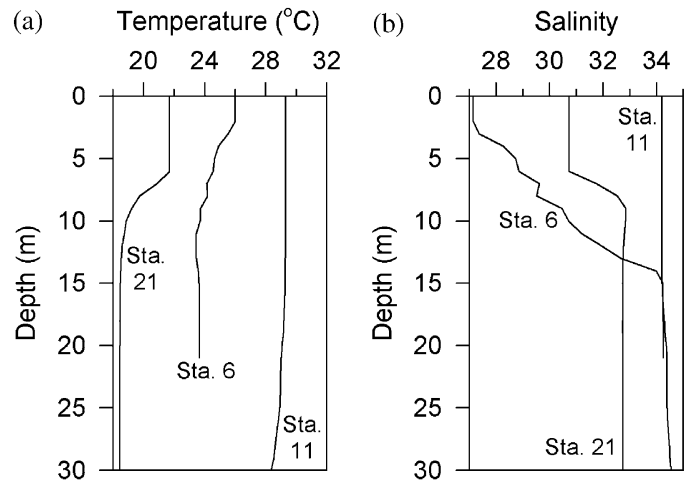

(c)

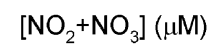

(d)
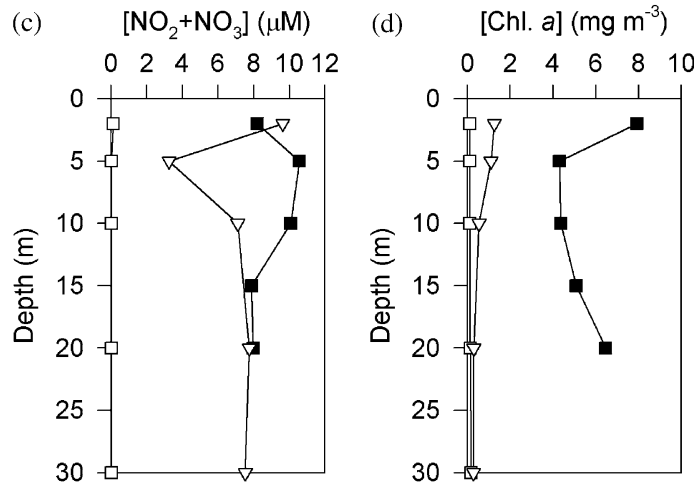

$\rightarrow$ Sta. 6 (coastal), $\rightarrow$ Sta. 21 (midshelf), $\square-$ Sta. 11 (Kuroshio)

Fig. 3. Hydrographic characteristics at three representative stations in the East China Sea: (a) temperature profiles; (b) salinity profiles; (c) nitrate and nitrite concentration profiles; (d) chlorophyll $a$ concentration profiles. and tidal movements (Fig. 2b). The nutrient concentrations in the coastal zone were high, especially at the northern stations near the Chang Jiang (Yangtze) River plume (Fig. 2c and d). The Kuroshio station at the shelf break (Sta. 11), however, was characterized by waters with high salinity but almost non-detectable nitrate and nitrite (Fig. $3 \mathrm{~b}$ and c). Chlorophyll $a$ concentrations were also low, in a range between 0.10 and $0.18 \mathrm{mg} \mathrm{m}^{-3}$ (Fig. 3d). Station 21 was selected as a representative midshelf station although its location was near the edge of the Chang Jiang River plume (Fig. 1). The nitrate/ nitrite level at this station was comparable to that at the coastal station, but the chlorophyll $a$ concentration was much lower, with the highest value, $1.3 \mathrm{mg} \mathrm{m}^{-3}$, near the surface (Fig. $3 \mathrm{c}$ and d). A more detailed description of hydrography and nutrient distribution was provided in Gong et al. (2003).

\subsection{POC and chlorophyll a concentrations}

When POC concentrations measured at 2-m depths at all 34 stations were plotted against chlorophyll $a$ concentrations, the lack of a linear relationship indicated that both C:chl $a$ and non-phytoplankton carbon may vary spatially in the East China Sea (Fig. 4a). After the removal of the most inshore stations from each of the cross-shelf transects (i.e., Stas. 4-6, 18, 19, 29, 30), POC concentrations at the remaining stations could be fitted to a regression line with a statistically significant slope $(\mathrm{C}: \mathrm{chl} \quad a)$ of $92.8 \mathrm{~g} \mathrm{~g}^{-1}$ (Table 1, Fig. 4a). The POC concentrations at coastal stations, on the other hand, were loosely scattered along a line with a different slope, but a meaningful regression coefficient could not be obtained (Fig. 4a). The value at Sta. 6 seemed to be an outlier, but hydrographical characteristics at this station did not differ substantially from other coastal stations (Fig. 2). Since additional samples from greater depths were available at 4 out of the 7 coastal stations, the inclusion of 5-m data from Stas. 4, 5, 29, and 30 generated a C:chl $a$ ratio of $13.0 \mathrm{~g} \mathrm{~g}^{-1}$ using Model I regression (Table 1, Fig. 4b). 

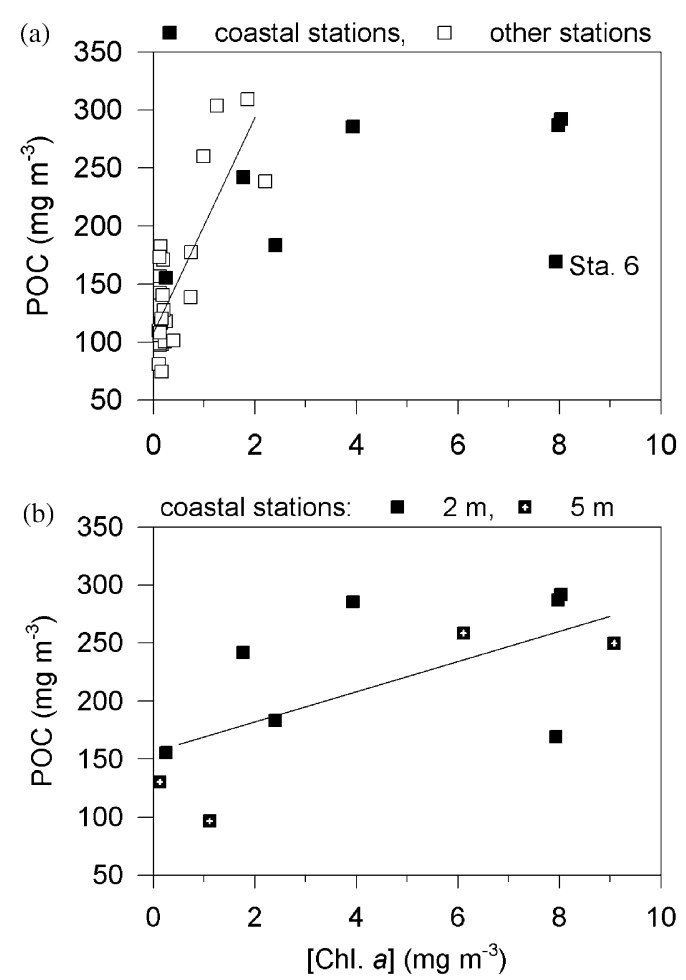

Fig. 4. Relationship between POC and chlorophyll $a$ concentrations in the East China Sea. (a) The relationship at 2-m depths. The solid line is the regression line for stations in the midshelf and the Kuroshio zones $(\mathrm{POC}=108.2+92.8$ [Chl. a], $P<0.001, r^{2}=0.65$ ). (b) Relationship between POC and chlorophyll $a$ concentrations in the coastal zone after the inclusion of data at 5-m depths. The regression equation (solid line $)$ is POC $=156.0+13.0$ [Chl. $a]\left(P<0.05, r^{2}=0.43\right)$.

\subsection{Cell volume and phytoplankton carbon}

At Sta. 6 in the coastal zone, a chain-forming diatom, Skeletonema costatum, formed a dense bloom with a population density of $5.3 \times 10^{6}$ cells $1^{-1}$ (Table 2). This abundance level translated to $107.8 \mathrm{mg} \mathrm{C} \mathrm{m}^{-3}$, and contributed $75.5 \%$ to total phytoplankton carbon. The next largest contributor was Synechococcus spp., followed by redfluorescing ultraplankton and small pennate diatoms. Dinoflagellates were frequently observed in this sample with Prorocentrum spp. being the numerically dominant group, reaching $2.2 \times 10^{3}$ cells $1^{-1}$. However, dinoflagellates contributed only $3.5 \%$ to total phytoplankton carbon. The
Table 1

Carbon-to-chlorophyll $a$ ratios $\left(\mathrm{g} \mathrm{g}^{-1}\right)$ estimated using the POC regression method and the cell volume method in the East China Sea

\begin{tabular}{llll}
\hline Method & Location & C:chl $a$ & $\begin{array}{l}95 \% \\
\text { Confidence } \\
\text { limits }\end{array}$ \\
\hline POC regression & $\begin{array}{l}\text { Coastal zone } \\
\text { Midshelf and }\end{array}$ & 13.0 & $1.68-24.3$ \\
& $\begin{array}{l}\text { Kuroshio zones } \\
\text { Cell volume }\end{array}$ & & $64.7-120.9$ \\
& Coastal zone & 18.0 & - \\
& Midshelf zone & 67.4 & - \\
& Kuroshio zone & 94.4 & - \\
\hline
\end{tabular}

total phytoplankton carbon at this station was $142.8 \mathrm{mg} \mathrm{Cm}^{-3}$, and the $\mathrm{C}: \mathrm{chl} a$ ratio was $18.0 \mathrm{~g} \mathrm{~g}^{-1}$ (Table 1).

Compared to the coastal station, the abundance of diatoms decreased dramatically at the midshelf station, and $S$. costatum was no longer the dominant species (Table 2). One of the major contributors to phytoplankton carbon at this station was Pseudosolenia calcar-avis, a large chain-forming diatom with cell lengths easily exceeding $500 \mu \mathrm{m}$. Other important phytoplankton species in terms of carbon content were Synechococcus spp. with an abundance comparable to that at Sta. 6. Small athecate dinoflagellates were also abundant, but their contribution to phytoplankton carbon was negligible due to their small size (Table 2). The phytoplankton carbon biomass and C:chl $a$ were estimated to be $84.4 \mathrm{mg} \mathrm{Cm}^{-3}$ and $67.4 \mathrm{gg}^{-1}$, respectively (Table 1).

The abundance of diatoms continued to decrease at the Kuroshio station (Sta. 11), and the dominant species of phytoplankton became the filamentous cyanobacteria Trichodesmium spp. (Table 2). This group alone contributed $62.6 \%$ to the total phytoplankton carbon at this station. Other phytoplankton with noticeable carbon biomass included Synechococcus spp. and assorted flagellates in the size range of 5 to $15 \mu \mathrm{m}$. However, since the overall abundance of phytoplankton was low, the estimated carbon biomass was only $9.9 \mathrm{mg}$ $\mathrm{C} \mathrm{m}^{-3}$ (Table 2). The estimated C:chl $a$ ratio was $94.4 \mathrm{~g} \mathrm{~g}^{-1}$ (Table 1). 
Table 2

Dominant phytoplankton species at individual stations and their contribution to autotrophic carbon based on cell volume measurements

\begin{tabular}{|c|c|c|c|c|}
\hline Phytoplankton & $n^{\mathrm{a}}$ (cells) & Cell volume $\left(\mu \mathrm{m}^{3}\right)$ & Abundance (cells $1^{-1}$ ) & Carbon $^{\mathrm{b}}\left(\mathrm{mg} \mathrm{m}^{-3}\right)$ \\
\hline \multicolumn{5}{|l|}{ Sta. 6 - coastal } \\
\hline Skeletonema costatum & 32 & $48 \sim 686$ & $5.3 \times 10^{6}$ & 107.8 \\
\hline Synechococcus spp. & 43 & $0.03 \sim 2.14$ & $8.2 \times 10^{7}$ & 14.8 \\
\hline Other species & & & & 20.2 \\
\hline Total & & & & 142.8 \\
\hline \multicolumn{5}{|l|}{ Sta. 21 -midshelf } \\
\hline Synechococcus spp. & 31 & $0.3 \sim 2.14$ & $7.2 \times 10^{7}$ & 36.9 \\
\hline Pseudosolenia calcar-avis & 6 & $0.6 \sim 3.3 \times 10^{6}$ & $1.2 \times 10^{3}$ & 29.6 \\
\hline Chaetoceros spp. & 14 & $2.5 \sim 57 \times 10^{3}$ & $9.1 \times 10^{3}$ & 6.4 \\
\hline Other species & & & & 11.5 \\
\hline Total & & & & 84.4 \\
\hline \multicolumn{5}{|l|}{ Sta. 11-Kuoshio } \\
\hline Trichodesmium spp. & & & $564^{\mathrm{c}}$ & $6.2^{\mathrm{d}}$ \\
\hline Nanoflagellates $(5 \sim 10 \mu \mathrm{m})$ & 11 & $78 \sim 624$ & $2.2 \times 10^{4}$ & 0.9 \\
\hline Nanoflagellates $(10 \sim 15 \mu \mathrm{m})$ & 11 & $48 \sim 838$ & $1.4 \times 10^{4}$ & 0.8 \\
\hline Synechococcus spp. & 2 & 0.13 & $6.5 \times 10^{6}$ & 0.5 \\
\hline Proboscia lata & 1 & $2.3 \times 10^{5}$ & $1.0 \times 10^{2}$ & 0.4 \\
\hline Other species & & & & 1.1 \\
\hline Total & & & & 9.9 \\
\hline
\end{tabular}

${ }^{\mathrm{a}}$ Number of cells measured for cell volume determination.

${ }^{\mathrm{b}}$ Phytoplankton carbon biomass.

${ }^{\mathrm{c}}$ Units: trichomes $1^{-1}$.

${ }^{\mathrm{d}}$ Computed using $0.011 \mu \mathrm{g} \mathrm{C}$ trichome ${ }^{-1}$ as the conversion factor (Carpenter, 1983).

\subsection{Phytoplankton growth rates in the East China Sea}

When phytoplankton carbon biomass estimated by the cell volume method was plotted against the logarithm of chlorophyll $a$ concentration, a linear relationship was established between these two parameters (Fig. 5a). Using this relationship, phytoplankton carbon at all stations with chlorophyll $a$ measurements could be estimated. On the other hand, the primary productivity measured at 18 stations ranged from 0.2 to $427 \mathrm{mg} \mathrm{C} \mathrm{m}^{-3}$ day $^{-1}$ (Fig. 6a). With these two pieces of information, phytoplankton growth rates in the East China Sea could be calculated using Eq. (1). The calculated growth rates ranged from 0 to $2.53 \mathrm{day}^{-1}$ with a clear cross-shelf gradient (Fig. 6b). Growth rates were very high in the coastal zone and gradually decreased toward the Kuroshio.

\section{Discussion}

Both the POC regression method and the cell volume method indicated strong variation of $\mathrm{C}: \mathrm{chl}$ $a$ values in the East China Sea, with low values in the coastal zone and high values in regions more offshore (Table 1). This result did not change if other strategies of grouping stations, such as by chlorophyll $a$ concentration or salinity, were used in the process of POC regression (data not shown). However, using the most inshore stations of each transect as the grouping criterion generated the best results with respect to statistical significance. Of course, the observed range of C:chl $a$ from 13.0 to $94.4 \mathrm{~g} \mathrm{~g}^{-1}$ represented variability at shallow depths $(2-5 \mathrm{~m})$ only, and the ratio would surely change at greater depths. When the POC regression method was applied to data collected at 40-m depths, the estimated C:chl $a$ was $36.1 \mathrm{gg}^{-1}$ 

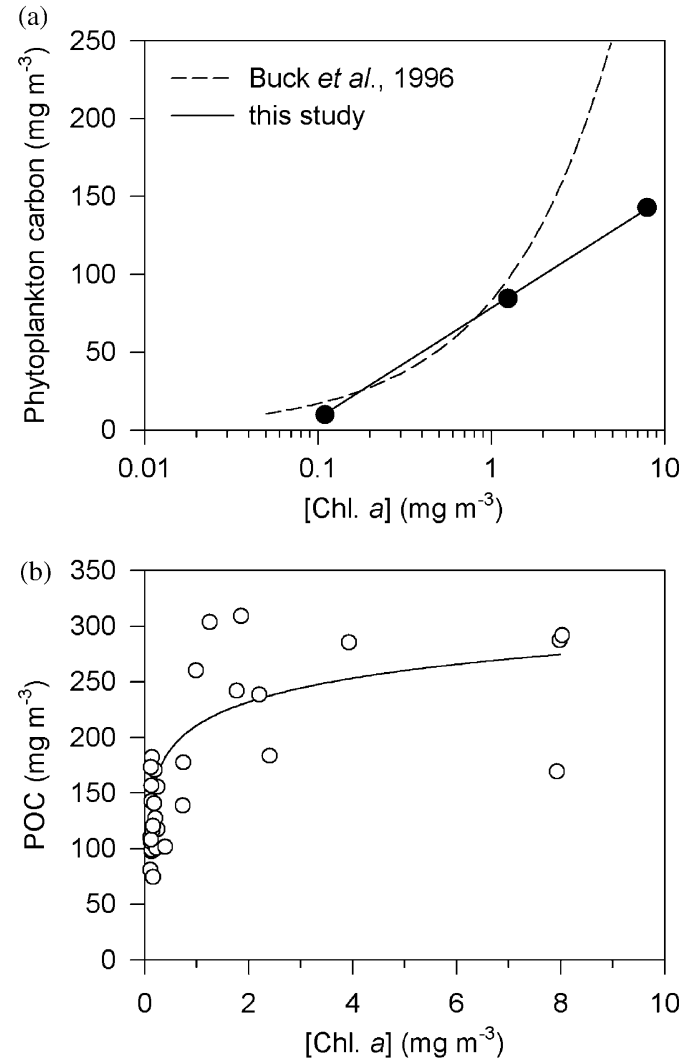

Fig. 5. Relationship between phytoplankton carbon $\left(C_{\mathrm{P}}\right)$ and chlorophyll $a$ concentration in the East China Sea. (a) The logarithmic model (solid line) based on phytoplankton carbon estimated by the cell volume method at three representative stations (-), and the regression equation is: $C_{\mathrm{P}}=78.6+$ $70.7 \log _{10}$ [Chl. $a$ ] $\left(P<0.01, r^{2}=0.99\right)$. The dashed curve is phytoplankton carbon biomass estimated by the model of Buck et al. (1996). (b) A comparison between the measured POC concentrations $(O)$ and those estimated by adding a constant non-phytoplankton carbon of $129 \mathrm{mg} \mathrm{m}^{-3}$ to $C_{\mathrm{P}}$ values from the logarithmic model.

(Chang, unpublished). This value is well within the 10 to $52 \mathrm{~g} \mathrm{~g}^{-1}$ range reported for the subsurface chlorophyll maximum (Furuya, 1990; Christian and Karl, 1994), but its accuracy needs further verification.

In the determination of abundance and cell volume using microscopy, several phytoplankton species may have been overlooked. Some autotrophic picoplankton, such as Prochlorococcus, are difficult to detect by epi-fluorescence microscopy. Although abundant Prochlorococcus are usually
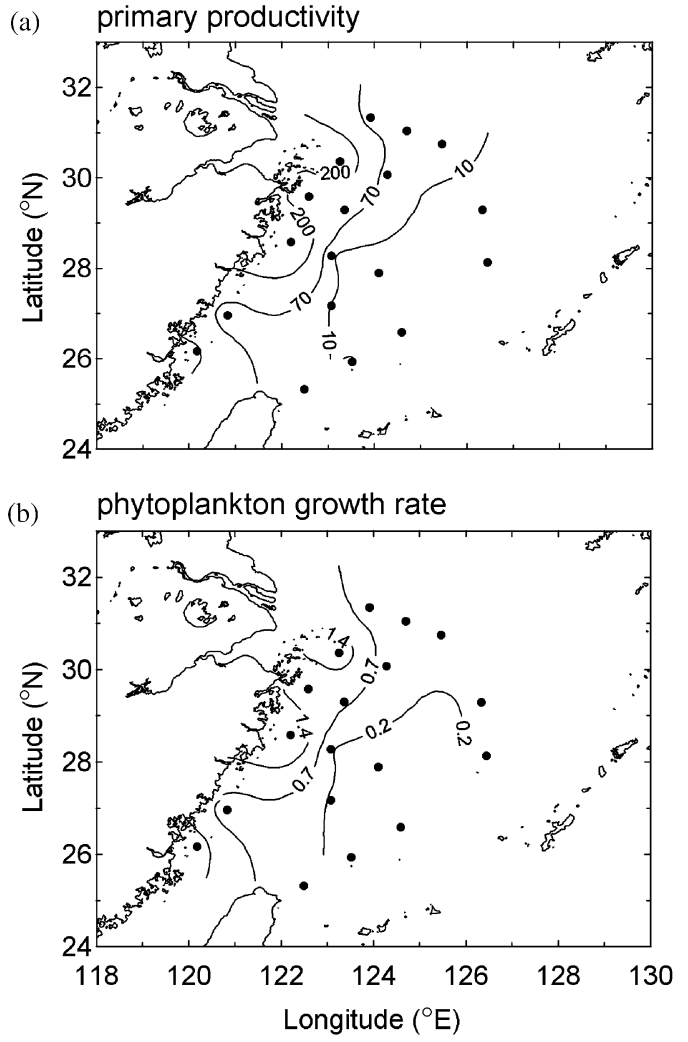

Fig. 6. Spatial variation of (a) primary productivity $\left(\mathrm{mg} \mathrm{C} \mathrm{m}^{-3}\right.$ day $^{-1}$ ) and (b) phytoplankton growth rates $\left(\mathrm{day}^{-1}\right)$ in the East China Sea. Phytoplankton growth rates were calculated using carbon biomass from the logarithmic model and primary productivity data.

observed in the open ocean, its presence in several neritic locations has been documented (reviewed in Partensky et al., 1999). The distribution of Proclorococcus in the East China Sea and its contribution to phytoplankton carbon need further investigation. In addition, acidic Lugol's can dissolve coccoliths and makes the identification of coccolithophorids impossible. However, most coccolithophorids observed in the East China Sea and nearby locations are smaller than $5 \mu \mathrm{m}$ in size (Yang et al., 2001), and this group of phytoplankton in our samples was most likely preserved on the Nuclepore filters and counted as red-fluorescing ultraplankton.

No perfect way exists for converting chlorophyll $a$ concentration to phytoplankton carbon, and the causes of errors have been fully documented 
(Banse, 1977; Cullen, 1982). For example, both detrital and zooplankton carbon in the water column may vary together with phytoplankton carbon, thus violating the assumption of the POC regression method (Banse, 1977). In the other method, simplifications in the estimation of cell volume are inevitable, and a certain amount of variation is always involved in the regression equation when converting cell volume to carbon (Mullin et al., 1966; Strathmann, 1967). However, these error-causing factors seemed to have a small influence on our estimates in the East China Sea, and the C:chl $a$ ratios estimated by the two independent methods were in close agreement (Table 1). In the coastal zone, hydrographical characteristics changed dramatically from one station to another (Fig. 2), and this high variability made it difficult to obtain a statistically sound relationship between chlorophyll $a$ and POC concentrations (Fig. 4a). Nevertheless, the four sets of measurement done at 5-m depths showed a trend similar to that at $2-\mathrm{m}$ depths, and the combined data set generated a $\mathrm{C}: \mathrm{chl} a$ ratio almost identical to that estimated by the cell volume method (Fig. 4b). These facts suggest that a common $\mathrm{C}: \mathrm{chl} a$ ratio exists in the coastal zone despite the heterogeneous nature of this region.

Compared to C:chl $a$ values reported in the literature, our estimate of 92.8 and $94.4 \mathrm{~g} \mathrm{~g}^{-1}$ in the Kuroshio zone was similar to the $98 \pm 33 \mathrm{gg}^{-1}$ observed at $10-\mathrm{m}$ depths in the North Pacific between 10 and $30^{\circ} \mathrm{N}$ (Furuya, 1990). In coastal waters at the northeastern corner of the East China Sea near Japan, C:chl $a$ was estimated to be $19-41 \mathrm{~g} \mathrm{~g}^{-1}$ for phytoplankton with a size greater than $10 \mu \mathrm{m}$ (Yamamoto, 1995). Agreeably, a C:chl $a$ ratio of $18 \mathrm{~g} \mathrm{~g}^{-1}$ was estimated for the coastal station near mainland China (Table 1). The high C:chl $a$ ratio observed in the oligotrophic Kuroshio zone is likely a result of the high-light and low-nutrient environment there, and this result is in accordance with observations of cultured phytoplankton (Geider et al., 1997; Taylor et al., 1997). In addition, phytoplankton species composition may contribute to the observed spatial variation. The phytoplankton communities in the midshelf and the Kuroshio zone were dominated by cyanobacteria, with phycoerythrin and phyco- cyanin as the major photosynthetic pigments (Table 2); C:chl $a$ of cyanobacteria is known to be higher than that of diatoms under similar growth conditions (Geider, 1993). Similarly, Trichodesmium trichomes in marine environments typically have a high $\mathrm{C}: \operatorname{chl} a$ ratio of around $200 \mathrm{gg}^{-1}$ (Carpenter, 1983).

The relationship between phytoplankton carbon and chlorophyll a concentration depicted in Fig. 5a seems to be a good way to eliminate the conflict caused by the two linear equations from the POC regression method (Fig. 4). Since the chlorophyll a concentrations observed in the coastal zone are not always higher than those in the region more offshore, the two linear regression equations overlap in the scale of chlorophyll $a$ between 0.25 and $2.2 \mathrm{mg} \mathrm{m}^{-3}$. Within this interval, substituting one equation for the other will generate vastly different estimates for phytoplankton carbon. The benefit of using the logarithmic model from the cell volume method is that it introduces a smooth prediction curve into this range of intermediate chlorophyll $a$ concentrations (Fig. 5). To demonstrate that the logarithmic model is an acceptable estimator of phytoplankton carbon in the East China Sea, the calculated phytoplankton carbon was added to a background non-phytoplankton carbon of $129 \mathrm{mg} \mathrm{Cm}^{-3}$, obtained by averaging the constant terms of the two linear equations, to estimate POC concentration. As a result, the estimated values fit reasonably well to the measured POC concentrations (Fig. 5b).

To some extent, phytoplankton carbon biomass in the East China Sea can be estimated by an empirical relationship developed for the North Atlantic Ocean (Buck et al., 1996), which indicates a smooth transition in C:chl $a$ between the open ocean and the shelf sea (Fig. 5). However, in the coastal zone where chlorophyll concentrations exceed $1 \mathrm{mg} \mathrm{m}^{-3}$, the model of Buck et al. (1996) overestimates phytoplankton carbon by a factor of as much as 2.4. In comparison, the logarithmic model generated by this study is more appropriate for the conversion between chlorophyll $a$ measurements and phytoplankton biomass in the East China Sea (Fig. 5). Nevertheless, this model is still far from perfect. First, it was established based on 
data from a single cruise at three stations. Second, this model estimates negative carbon biomass at chlorophyll a concentrations lower than $0.08 \mathrm{mg} \mathrm{m}^{-3}$, which is obviously unreasonable.

Phytoplankton growth rates calculated using primary productivity and carbon biomass clearly revealed a cross-shelf gradient (Fig. 6b). Interestingly, the growth rate of the unicellular cyanobacteria, Synechococcus spp., measured by the selective inhibitor technique during the same cruise, showed a very similar trend (Chang et al., 2003). Judging from the salinity and nutrient distribution patterns in the East China Sea (Fig. 2), the growth of phytoplankton in summer is most likely controlled by a terrestrial-originated substance. However, in the nutrient-rich coastal zone, the estimated growth rates varied greatly from one station to another (Fig. 6b). These sporadic high growth rates were not caused by errors associated with the calculation of phytoplankton carbon since the measured primary productivities in the coastal zone have the same degree of variation (Fig. 6a). Although phosphate has been suggested as a limiting nutrient in coastal waters of China (Harrison et al., 1990; Wong et al., 1998), high concentration of phosphate did not stimulate phytoplankton growth at Sta. 18 (Figs. 2 and 6). In contrast, growth rates exceeded 1.4 day $^{-1}$ at Stas. 4, 29, and 30 whereas phosphate concentrations at these stations were rather low. The mechanism that introduces the mosaic pattern of phytoplankton growth in the coastal zone thus is difficult to identify based on distribution patterns alone.

\section{Acknowledgements}

We thank B.-W. Wang, K.-J. Liu, and Y.-H. Wen for their assistance in measuring primary production, and M.-C. Kuo for her assistance in processing part of the ultraplankton samples. This research was supported by grants NSC 88-2611M-019-012-K2 (to JC), NSC 89-2611-M-002-007K2 (to FKS), NSC 88-2611-M-019-011-K2 (to GCG), and NSC 88-2611-M-019-004-K2 (to KPC) from the National Science Council of the Republic of China.

\section{References}

Banse, K., 1977. Determining the carbon-to-chlorophyll ratio of natural phytoplankton. Marine Biology 41, 199-212.

Bradbury, S., 1991. Basic Measurement Techniques for Light Microscopy. Oxford University Press, New York, 97 pp.

Buck, K.R., Chavez, F.P., Campbell, L., 1996. Basin-wide distributions of living carbon components and the inverted tropic pyramid of the central gyre of the North Atlantic Ocean, summer 1993. Aquatic Microbial Ecology 10, 283-298.

Carpenter, E.J., 1983. Physiology and ecology of marine planktonic Ocsillatoria (Trichodesmium). Marine Biology Letters 4, 69-85.

Chang, J., Lin, K.-H., Chen, K.-M., Gong, G.-C., Chiang, K.-P., 2003. Synechococcus growth and mortality rates in the East China Sea: range of variations and correlation with environmental factors. Deep-Sea Research II, this issue

Cho, B.C., Azam, F., 1990. Biogeochemical significance of bacterial biomass in the ocean's euphotic zone. Marine Ecology Progress Series 63, 253-259.

Christian, R.J., Karl, D.M., 1994. Microbial community structure at the US-Joint Global Ocean Flux Study Station ALOHA: inverse methods for estimating biochemical indicator ratios. Journal of Geophysical Research 99, 14269-14276.

Cloern, J.E., Grenz, C., Vidergar-Lucas, L., 1995. An empirical model of the phytoplankton chlorophyll: carbon ratio- the conversion factor between productivity and growth rate. Limnology and Oceanography 40, 1313-1321.

Cullen, J.J., 1982. The deep chlorophyll maximum: comparing vertical profiles of chlorophyll $a$. Canadian Journal of Fisheries and Aquatic Sciences 39, 791-803.

Furuya, K., 1990. Subsurface chlorophyll maximum in the tropical and subtropical western Pacific Ocean: vertical profiles of phytoplankton biomass and its relationship with chlorophyll $a$ and particulate organic carbon. Marine Biology 107, 529-539.

Furuya, K., Nemoto, T., 1986. Cell volume and chemical composition (C, N). In: Matsumoto, E. (Ed.), A Manual for Coastal Environment Investigation. Oceanographic Society of Japan, Tokyo, pp. 149-153.

Geider, R.J., 1993. Quantitative phytoplankton physiology: implications for primary production and phytoplankton growth. ICES Marine Science Symposia 197, 52-62.

Geider, R.J., MacIntyre, H.L., Kana, T.M., 1997. Dynamic model of phytoplankton growth and acclimation: responses of the balanced growth rate and the chlorophyll $a$ : carbon ratio to light, nutrient-limitation and temperature. Marine Ecology Progress Series 148, 187-200.

Gong, G.-C., 1992. Chemical hydrography of the Kuroshio front in the sea northeast of Taiwan. Ph.D. Thesis, Institute of Oceanography, National Taiwan University, 204 pp.

Gong, G.-C., Yang, W.-R., Wen, Y.-H., 1993. Correlation of chlorophyll $a$ concentration and Sea Tech fluorometer 
fluorescence in seawater. Acta Oceanographica Taiwanica $31,117-126$.

Gong, G.-C., Wen, Y.-H., Wang, B.-W., Liu, G.-J., 2003. Seasonal variation of chlorophyll $a$ concentration, primary production and environmental conditions in the subtropical East China Sea. Deep-Sea Research Part II, this issue

Guillard, R.R.L., 1978. Counting slides. In: Sournia, A. (Ed.), Phytoplankton manual. United Nations Educational, Scientific and Cultural Organization, Paris, pp. 182-189.

Harrison, P.J., Hu, M.H., Yang, Y.P., Lu, X., 1990. Phosphate limitation in estuarine and coastal waters of China. Journal of Experimental Marine Biology and Ecology 140, 79-87.

Hillebrand, H., Durselen, C.-D., Kirschtel, D., Pollingher, U., Zohary, T., 1999. Biovolume calculation for pelagic and benthic microalgae. Journal of Phycology 35, 403-424.

Jassby, A.D., Platt, T., 1976. Mathematical formulation of the relationship between photosynthesis and light for phytoplankton. Limnology and Oceanography 21, 540-547.

Liu, K.-K., Lai, Z.-L., Gong, G.-C., Shiah, F.-K., 1995. Distribution of particulate organic matter in the southern East China Sea: implications in production and transport. Terrestrial, Atmospheric and Oceanic Sciences 6, 27-45.

Mullin, M.M., Sloan, P.R., Eppley, R.W., 1966. Relationship between carbon content, cell volume, and area in phytoplankton. Limnology and Oceanography 11, 307-311.

Parsons, T.R., Maita, Y., Lalli, C.M., 1984. A manual of chemical and biological methods for seawater analysis. Pergamon Press, Oxford, 173 pp.

Partensky, F., Hess, W.R., Vaulot, D., 1999. Prochlorococcus, a marine photosynthetic prokaryote of global significance. Microbiology and Molecular Biology Reviews 63, 106-127.

Peng, T.-H., Hung, J.-J., Wanninkhof, R., Millero, F.J., 1999. Carbon budget in the East China Sea in spring. Tellus 51B, 531-540.

Redalje, D.G., Laws, E.A., 1981. A new method for estimating phytoplankton growth rates and carbon biomass. Marine Biology 62, 73-79.

Schaefer, C.T., Lewin, J., 1984. Persistent blooms of surf diatoms along the Pacific coast, USA. Marine Biology 83, 205-217.
Sokal, R.R., Rohlf, F.J., 1995. Biometry, 3rd. Edition. W. H. Freeman and Company, New York, 887 pp.

Strathmann, R.R., 1967. Estimating the organic carbon content of phytoplankton from cell volume or plasma volume. Limnology and Oceanography 12, 411-418.

Sukhanova, I.N., 1978. Settling without the inverted microscope. In: Sournia, A. (Ed.), Phytoplankton Manual. United Nations Educational, Scientific and Cultural Organization, Paris, p. 97.

Tomas, C.R., 1996. Identifying Marine Diatoms and Dinoflagellates. Academic Press, San Diego, 598 pp.

Taylor, A.H., Geider, R.J., Gilbert, F.J.H., 1997. Seasonal and latitudinal dependencies of phytoplankton carbon-to-chlorophyll a ratios: Results of a modeling study. Marine Ecology Progress Series 152, 51-66.

Verity, P.G., Robertson, C.Y., Tronzo, C.R., Andrews, M.G., Nelson, J.R., Sieracki, M.E., 1992. Relationships between cell volume and the carbon and nitrogen content of marine photosynthetic nanoplankton. Limnology and Oceanography 37, 1434-1446.

Wienke, S.M., Cloern, J.E., 1987. The phytoplankton component of seston in San Francisco Bay. Netherlands Journal of Sea Research 21, 25-33.

Wong, G.T.F., Gong, G.-C., Liu, K.K., Pai, S.-C., 1998. 'Excess nitrate' in the East China Sea. Estuarine, Coastal and Shelf Science 46, 411-418.

Wong, G.T.F., Chao, S.-Y., Li, Y.-H., Shiah, F.-K., 2000. The Kuroshio edge exchange processes (KEEP) study - an introduction to hypothesis and highlights. Continental Shelf Research 20, 335-347.

Yamamoto, T., 1995. Contribution of micro- and nanophytoplankton cell carbon to particulate organic carbon in the East China Sea during May 1980. Journal of the Faculty of Applied Biological Science, Hiroshima University 34, 147-160.

Yang, T.-N., Wei, K.-Y., Gong, G.-C., 2001. Distribution of coccolithophorids and coccoliths in surface ocean off northeastern Taiwan. Botanical Bulletin of Academia Sinica 42, 287-302. 